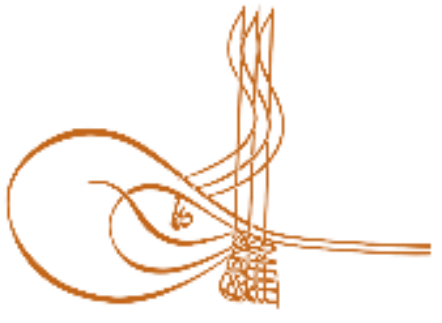

www.turkishstudies.net/social
Turkish Studies - Social Sciences

eISSN: $2667-5617$

Research Article / Araşttrma Makalesi

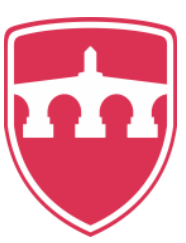

INTERNATIONAL

BALKAN

UNIVERSITY

Sponsored by IBU

\title{
Milli Kütüphane Yazma Eserler Koleksiyonu Osmanlı Dönemi Çiçek Bezemeli Cilt Kapaklari*
}

\author{
National Library Writing Works Collection Ottoman Period Flower Decorated Skin Covers
}

\author{
Şener Küçüktepe ${ }^{* *}$ - Abdulkadir Dündar ${ }^{* * *}$
}

\begin{abstract}
Art, in its most general definition, is a way of expression chosen by a person, a style of expression. Traditional arts have an important place in these ways of expression. One of these sub-branches is skin art. Volumes are the outer element of the book and are sources that shed light on the art understanding of the past as well as the knowledge they contain. Manuscripts have turned into cultural heritage because of these features. Nowadays, the volumes are kept in important libraries. One of the libraries kept is the "National Library". There are very rich examples of skin art in the library. In this study, using descriptive method, the books in the National Library A catalog; Leather binding covers of 8 manuscripts that have been determined to date from the Ottoman period have been handled chronologically and each volume has been documented in detail and aimed to be introduced. The mentioned works of art; The information regarding the qualitative features such as the scope, the periods they belong to, and the titles are arranged based on the data in the inventory. It is very important to keep the art of binding, establishing interconnection, Turkish culture, history, art and decoration.
\end{abstract}

Structured Abstract: The art of nations is an expression of their culture. Because the works of art are indicative of the nations' perspective to the world (Aslanapa, 1978: 591).

During the historical process, Turks brought many artworks to the geographies they lived in and transferred all kinds of cultural heritage to each other. Traditional arts are one of the most important indicators of a society's unique cultural heritage. According to centuries, the subject is in the art of binding in traditional arts, which differ in terms of the natural substance used, the technique and style applied. Volumes are sources that shed light on the art understanding of the past as well as the knowledge they contain.

\footnotetext{
* Bu makale Şener Küçüktepe'nin “Milli Kütüphane Yazma Eserler Koleksiyonu Osmanlı Dönemi (17-19. Yüzyıl) Cilt Kapakları" T.C. Ankara Üniversitesi Sosyal Bilimler Enstitüsü İslam Tarihi ve Sanatları Anabilim Dalı Türk İslam Sanatları Tarihi Bilim Dalı'nda hazırlamış olduğu doktora tezinden üretilmiştir.

** Doktora Öğrencisi, Ankara Üniversitesi, Sosyal Bilimler Enstitüsü, İslam Tarihi ve Sanatları Bölümü PhD. Student, Ankara University, Faculty of Theology, Department of Islamic History and Arts ORCID 0000-0001-5224-8479

skucuktepe@outlook.com

**** Prof. Dr., Ankara Üniversitesi, İlahiyat Fakültesi, İslam Tarihi ve Sanatları Bölümü

Prof. Dr., Ankara University, Faculty of Theology, Department of Islamic History and Arts

ORCID 0000-0002-2713-6675

abdulkadirdundar@yahoo.com

Cite as/ Atıf: Küçüktepe, Ş., Dündar, A. (2020). Milli Kütüphane Yazma Eserler Koleksiyonu Osmanlı Dönemi çiçek bezemeli cilt kapaklar1, Turkish Studies - Social, 15(3), 1319-1336. https://dx.doi.org/10.29228/TurkishStudies.41606

Received/Geliş: 04 February/Şubat 2020

Checked by plagiarism software

Accepted/Kabul: 25 April/Nisan 2020

Published/Yayın: 30 April/Nisan 2020

Copyright (C) INTAC LTD, Turkey

CC BY-NC 4.0
} 
Today, most of the volumes are kept in archives, museums, private collections and libraries of public institutions and organizations. One of the libraries kept is the "National Library". National libraries have features and functions that distinguish them from other library types. The National Library performs tasks such as bibliographic supervision in the country, the organization of information resources, the creation of common cataloging rules, the implementation of international rules / standards and the communication / cooperation between libraries (Rukanc1; Anameriç, 2017: 81). In addition, they have the role of exemplifying and leading other types of libraries in the country. Therefore, all countries pay great attention to establishing a national library and equipping it with the best opportunities and running it effectively (Sefercioğlu, 2015: 12).

According to the records in the National Library, there are manuscripts consisting of A, B and cönkler catalogues consisting of various collections. Studies on the volumes of these works are very limited. With this work we will do, the manuscripts in catalog A in the National Library; According to the data obtained from the inventories, the leather binding covers of 8 manuscripts determined to have survived from the Ottoman Period have been examined. Volumes were handled chronologically and each volume was documented in detail. In the evaluation section, the sections that make up the skin, the decorations on the skin, the techniques used in making the skin, the colors used and the decorations were analyzed in detail. In addition, the mentioned works of art; The information regarding the qualitative features such as the scope, periods they belong to, and the titles are arranged based on the data in the inventory.

With the effect of the naturalism trend, traditional plant forms have been seen as flowers in the naturalist style since the mid-16th century (Demiriz, 2019: 15). The volumes we dated to the century were made as cold sunburst (Example No: 1) and malemma sunburst (Example No: 2). In the ornamentation of sunburst, flowers are observed in partially symmetrical composition coming out of the vase. There are roses, carnations, jonquil, tulips, and stylized, unidentified flowers. The error pattern was also used on the surface of the miclape (Example No: 1). Mülemma is decorated with a composition of rose bunches on the surface of the umbrellas. It is decorated with unidentified flowers at the exit point of the rose bundle (Example No: 2).

On the covers of the works we have dated to the 18th century, it is seen that the continuation of the floral decoration subjects of the 17th century has been applied. The surface of the sunflower, which is designed as the skin of Mülemma sunflower, is a mixed bouquet. The bouquet is tied from the stem. Below are roses, rosebuds above, granules and unidentified flowers. The Miklep umbrella is also decorated with paw and leaf motifs (Example No: 3). During this period, there are two cold suns. The first of these volumes consists of three jonquil flowers, buds and leaves, whose surface comes out of the pot. On the surface of the Salbek and miclape umbrellas, the flower of the granule was applied (Example No: 4). On the other, there are roses, rosebuds and flowers in stylized composition coming from the vase on the surface (Example No: 5).

In the 19th century, writing volumes were arranged in the painting technique and the decoration of the works is different from each other. Mobility has been brought to the decoration by using different shades of gold and silver on the covers decorated with painting technique. As a feature of the period, flowers made in the form of $\mathrm{S}$ and $\mathrm{C}$ folds dominate the surface. Daisies are placed between the leaves on a branch in the cover centers (Example No: 7). There are rose, rosebuds and leaves on the S-shaped branch, which is painted with silver and gold. In the center of the cap, the paw motif is decorated with leaves carried by the folded branches coming out of the motif (Example No: 8).

In our research on the volumes in the National Library A catalog, eight volumes that were the subject of the study were identified in the National Library Manuscripts Collection. The information in the inventory records was used in the selection of the works. When we evaluate the works in terms of material, color, technique, skin and cover decoration features, two are 17th century (Example No: 1,2), three are 18th century (Example No: 3, 4, 5) and three are 19th century (Example No: 6, 7, 8). Although one of the studied works was taken over in the 15 th century, the covers were renewed in the 18 th century.

The bookbinders of the works we have examined are not certain. All of the examined skins are made of leather and leather is used in all of them. In skin making, one-color leather was applied and the works were covered with brown, burgundy, green, cherry and black leather. While a work has a zerefşan ornament on the inner cover, other inner covers are not seen.

While the printing technique was seen in the 17th and 18th century, the painting technique was seen in the 19th century. Skin was applied to the cold sun, skin to the sun and writing skin was applied. In the 17 th and 18th centuries, narrow, long, bulging, sliced and rectangular shaped umbrellas are found, while an oval

Turkish Studies - Social, 15(3) 
scheme with a dummy appears on an 18th century volume. In the 19th century, they are the umbrellas that are handled to cover almost the entire surface seen on the volumes. Skin covers are adorned with naturalist style flowers. While the depictions of flowers used in decoration are composed of roses, carnations, jonquil, tulips and daisies; It can be seen in baroque and rococo style decorations.

Manuscripts are the most reliable sources of science, art and culture research. Transferring the correct and qualified works to the next generations in binder art is important in terms of documenting our history, culture and art values and ensuring their continuity. It is thought that these works to be carried out in the field of our Traditional Arts will contribute to the promotion of our cultural treasures and the promotion of the country.

Keywords: Traditional Arts, Skin Art, Library, Embellishment, Flower

Öz: Sanat, en genel tanımıyla, insanın seçtiği bir anlatım yolu, bir anlatım tarzıdır. Bu anlatım yolları içinde geleneksel sanatlar önemli bir yer tutar. Geleneksel sanatlar hat, tezhip, minyatür gibi el sanatı ürünlerini kapsayan alt kollara ayrılmıştır. Bu alt dallardan bir tanesi de cilt sanatıdır. Ciltler kitabın dış öğesidir ve içerdikleri bilgi birikiminin yanı sıra, geçmişin sanat anlayışına da ş̧ık tutan kaynaklardır. Yazma eserler bu özelliklerinden dolayı kültür mirasına dönüşmüştür. Günümüzde ciltlerin önemli bir kısmı kamu kurum ve kuruluşuna ait arşivlerde, müzelerde, özel koleksiyonlarda ve kütüphanelerde muhafaza edilmektedir. Muhafaza edilen kütüphanelerden biri de "Milli Kütüphane" dir. Kütüphanede cilt sanatının çok zengin örnekleri mevcuttur. Bu çalışmada betimsel yöntem kullanılarak, Milli Kütüphane A kataloğunda bulunan kitapların; Osmanlı Döneminden günümüze ulaştığı belirlenen 8 adet yazma esere ait deri cilt kapağı kronolojik olarak ele alınmış ve her cilt ayrıntılı olarak fotoğraflarıyla belgelenerek tanıtılması amaçlanmıştır. Değerlendirme bölümünde de cildi oluşturan bölümler, cilt üzerinde yer alan süslemeler, cilt yapımında kullanılan teknikler, kullanılan renkler ve bezemelerde detaylı bir şekilde analiz edilmiştir. Ayrıca söz konusu yazma eserlerin; kapsam, ait oldukları dönemler ve eser isimleri gibi niteliksel özelliklerine ilişkin bilgiler envanterinde bulunan veriler esas alınarak düzenlenmiştir. Cilt sanatının yaşatılması, kuşaklar arası bağlantının kurulması, Türk kültürü, tarihi, sanatı, süslemesi açısından oldukça önemlidir.

Anahtar Kelimeler: Geleneksel Sanatlar, Cilt Sanatı, Kütüphane, Bezeme, Çiçek

\section{Giriş}

Milletlerin sanatı, onların kültürlerinin bir ifadesidir. Çünkü sanat eserleri milletlerin dünyaya bakış açılarının göstergesidir (Aslanapa, 1978: 591).

Türkler tarihi süreç içerisinde, yaşadıkları coğrafyalara pek çok sanat eseri kazandırmış ve birbirlerine her türlü kültürel mirası aktarmışlardır. Geleneksel sanatlar bir toplumun kendine özgü kültür mirasının en önemli göstergelerinden biridir. Yüzyıllara göre konu, kullanılan doğal madde, uygulanan teknik ve üslup bakımından farklılık gösteren geleneksel sanatlar içinde cilt sanatıda bulunmaktadır. Ciltler içerdikleri bilgi birikiminin yanı sıra, geçmişin sanat anlayışına da 1şık tutan kaynaklardır.

Günümüzde ciltlerin önemli bir kısmı kamu kurum ve kuruluşuna ait arşivlerde, müzelerde, özel koleksiyonlarda ve kütüphanelerde muhafaza edilmektedir. Muhafaza edilen kütüphanelerden biri de "Milli Kütüphane" dir. Milli kütüphanelerin, öteki kütüphane türlerinden ayıran özellikleri ve görevleri vardır. Milli Kütüphane ülkedeki bibliyografik denetim, bilgi kaynaklarının organizasyonu, ortak kataloglama kurallarının oluşturulması, uluslararası kuralları/standartları hayata geçirme ve kütüphaneler arası iletişimin/yardımlaşmanın sağlanması gibi görevleri yerine getirmektedir (Rukanc1; Anameriç, 2017: 81). Bunlara ek olarak, ülkedeki başka tür kütüphanelere örneklik ve önderlik etme görevleri vardır. Bunlardan dolayı bütün ülkeler milli kütüphane kurmaya ve onu en iyi imkânlarla donatmaya ve etkin çalıştırmaya büyük özen gösterirler (Sefercioğlu, 2015: 12).

Milli Kütüphane'de kayıtlara göre çeşitli koleksiyonlardan oluşan A,B ve cönkler katalaloğundan oluşan yazma eserler bulunmaktadır. Bu eserlerin ciltleri üzerine çalışmalar oldukça 
sınırlıdır. Bizim yapacağımız bu çalışma ile Milli Kütüphane'de A kataloğunda bulunan yazmaların; envanterlerinden elde edilen verilere göre Osmanlı Döneminden günümüze ulaştığı belirlenen 8 adet yazma eserlere ait deri cilt kapağı incelenmiştir. Ciltler kronolojik olarak ele alınmış ve her cilt ayrınlıtı olarak fotoğrafları ile belgenerek tanıtılmıştır. Değerlendirme bölümünde de cildi oluşturan bölümler, cilt üzerinde yer alan süslemeler, cilt yapımında kullanılan teknikler, kullanılan renkler ve bezemelerde detaylı bir şekilde analiz edilmiştir. Ayrıca söz konusu yazma eserlerin; kapsam, ait oldukları dönemler ve eser isimleri gibi niteliksel özelliklerine ilişkin bilgiler envanterinde bulunan veriler esas alınarak düzenlenmiştir.

\section{Cilt Sanatı ve Çiçekli Bezemeler}

Kitap sanatları içinde önemli bir yere sahip olan ve "bir kitabın elbisesi" olarak nitelendirebileceğimiz cilt, bir yazma eseri elimize aldığımızda karşılaştığımız ilk üründür (Kara, 2017: 161). Bir mecmua veya kitabın yapraklarını dağılmadan ve sırası bozulmadan bir arada tutabilmek için yapılan koruyucu kapağa cilt (cild) denilmektedir (Arıtan, 1993: 551). Cilt kelimesi Arapça kökenli olup deri anlamına gelmektedir (Arseven, 1983: 341). Bundan dolayı tanıtılan sanatın uygulamasına Türkçe'de teclîd, mesleğe ciltçilik (Derman, 2012: 149), bunu meslek edinenlere de mücellit denilmiştir (Özen, 1998: 9). "Mücellitlik" kitabın ciltlenmesini, "mücellithane" ise işin yapıldığı atölyeyi tanımlamaktadır (Binark, 1987: 91).

Türk Sanatın da figürlü bezeme sınırlı sayıda üretilmiş, buna karşılık geoetmetrik ve bitkisel formlar ile yazı, tüm bezeme sanatlarında en çok tercih edilen öğeler olmuştur. Özellikle çiçeğin, Osmanlı kültüründe özel bir yeri vardır. Doğal görünümleriyle resmedilen natüralist çiçekler 16. yüzyılın ortasından itibaren görülmektedir (Demiriz, 2019: 15). 17. ve 18. yüzyıllarda Avrupa barok ve rokoko üsluplarını görmeleriyle, 19. yüzyıl başalarında kitap cildi renk ve desen bakımından zenginleşti. Vazolar, sepet ve saksılar içinde buketler, demetler, iri çiçek ve yapraklar gölgeli boyanarak hacim kazandı (Tanındı, 2012: 26). Osmanlı kültüründe ve sanatında ön plana çıkan bazı çiçekler vardır. Süslemelerde bahçe çiçekleri seçilerek kullanılmıştır. Bunların başında gül, lale, karanfil, sümbül, zerrin gibi çiçekler gelir (Özkeçeci; Özkeçeci, 2014: 87). 
Milli Kütüphane Yazma Eserler Koleksiyonu Osmanlı Dönemi Çiçek Bezemeli Cilt Kapakları1323

\section{Milli Kütüphane Yazma Eserler Koleksiyonu Osmanlı Dönemi}

Çiçek Bezemeli Cilt Kapakları Eser İncelemesi

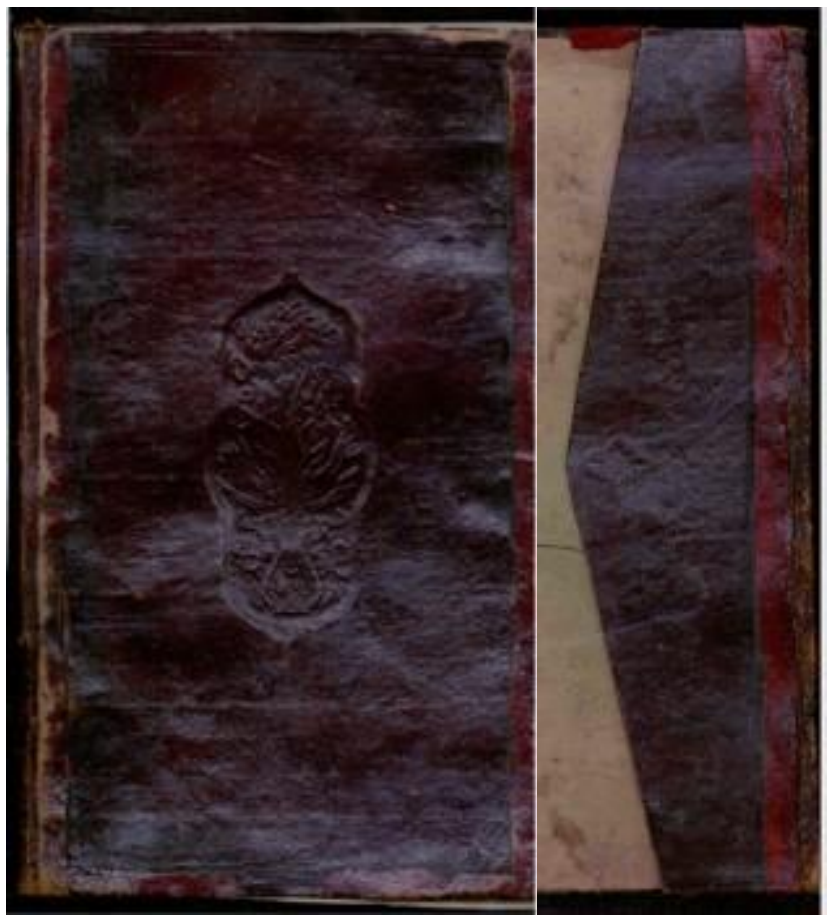

Örnek No: 1

Eser Adı: Keşfü'l-Hicâb'an Vechi'l-Kitâb

Bulunduğu Yer: Milli Kütüphane

Envanter No: 06 Mil Yz A 753

Konusu: İslâm Dini-Tasavvuf ve Tarikatlar

Müellif: Nev'î Yahyâ b. Alî Ma'alkaravî

Mücellit: Bilinmiyor

İstinsah Tarihi: Bilinmiyor

Ölçüleri: 210x125 - 146x65 mm.

Varak Sayısı: 162

Cilt Yapım Malzemesi: Deri-Meşin

Cilt Rengi: Bordo

Cilt Yapım Tekniği: Baskı Tekniği

Cilt Süslemesinde Kullanılan Renkler: Renk Kullanılmamış

Bezeme: Cildin ön ve arka kapağında aynı bitkisel bezmeye sahip soğuk şemse cilt yer almaktadır. Kitabın kapakları ve miklep aletle yapılmış üç sıra soğuk cetvel ile çerçevelenmiştir. Kapaklarda köşebent bezemesi yoktur.

Şemse kapak merkezinde dar, uzun, ortası șișkin, dilimli ve dikdörtgen formdadır. Şemse yüzeyinde vazodan çıkan kısmen simetrik kompozisyonda çiçekler görülür. Gül, karanfil, zerrin, 
laleler ve stilize, tanımlanamayacak çiçekler vardır. Bezeme hafif kabartma olarak kalıpla basılmıştır.

Miklep şemsesi palmet şeklinde hafif kabartmadır ve içerisinde hatayi motifi vardır.

Sertab ve sırt kırmızı renk bir deri ile onarım gördüğü için yüzey görülememiștir.

İç kapaklarında herhangi bir süsleme kompozisyonu bulunmamaktadır.

Tarihlendirme: “Keşfü'l-Hicâb'an Vechi'l-Kitâb” adlı eser "Nev'î Yahyâ b. Alî Ma'alkaravî" tarafından yazılmıştır. İstinsah tarihi belli değildir. Topkapı Sarayı Kütüphanesi E.H. 1722 envanter numarada kayıtlı 17. yüzyıl ikinci yarısına tarihlendirilen "Risale Mecmuası" adlı eser (Demiriz, 1986: 59) ile kapak şemse deseni bire bir benzemektedir. "Risale Mecmuası" şemse süslemesi; mülemma şemse olarak düzenlenmiştir. Eserle olan benzerliğinden dolayı cilt 17. yüzyılda yapılmış olmalıdır.

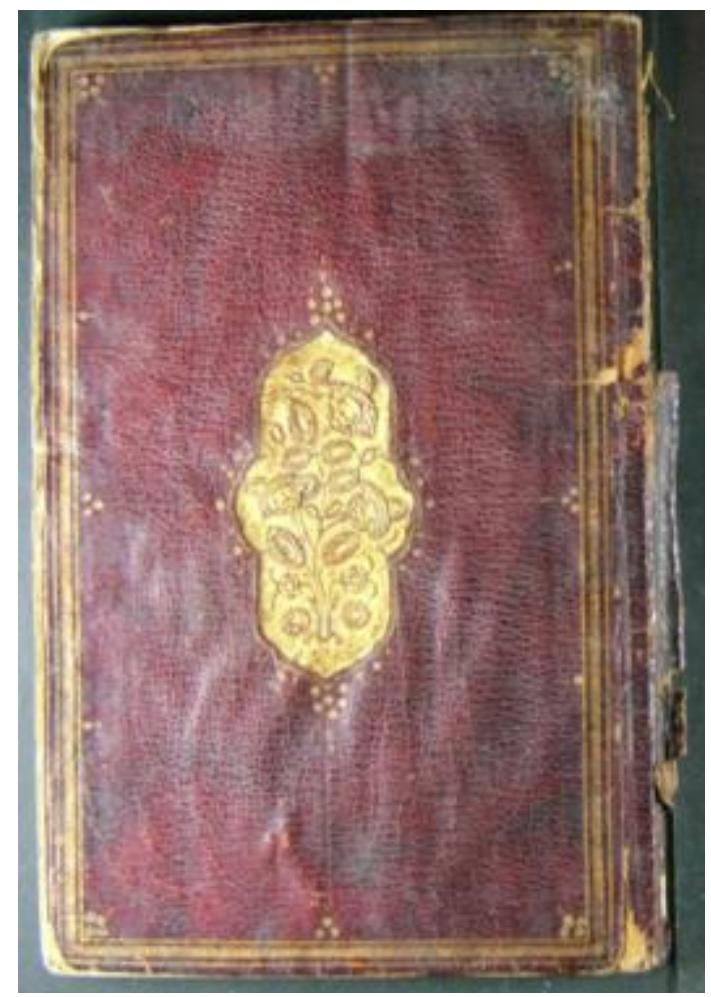

Örnek No: 2

Eser Adı: Mecmû'a-i Eş'âr ve Ed'îye

Bulunduğu Yer: Milli Kütüphane

Envanter No: 06 Mil Yz A 3985

Konusu: Mecmua

Müellif: Bilinmiyor

Mücellit: Bilinmiyor

İstinsah Tarihi: Bilinmiyor 
Ölçüleri: 200x130 mm.

Varak Sayısı: 46

Cilt Yapım Malzemesi: Deri-Meşin

Cilt Rengi: Vişne

Cilt Yapım Tekniği: Baskı Tekniği

Cilt Süslemesinde Kullanılan Renkler: Altın

Bezeme: Mülemma şemseli cilt olarak düzenlenen kitabın ön/ arka kapak süslemesi bitkisel motiflerle tezyin edilmiştir. Kapaklar altın cetveller arasında yer alan zencirek ile çerçevelenmiştir. Köşebent bezemesi olmayan ciltte köşeler, kısa ve uzun kenar ortalarında gülçe motifleri vardır.

Kapak ortasında dikdörtgen biçimli salbeksiz şemse yer almaktadır. Şemsenin uçları dilimli, orta kısmı dıșa doğru bombelidir. Gül demetinden oluşan kompozisyonla bezenmiștir. Gül demetinin çıkış noktasında tanımlanamayan çiçeklerde görülür. Şemse etrafi tahrirlenmiş, dilimler tığlarla ve gülçe motifleri ile vurgulanmıştır.

Kitabın sırt bölümü hasarlı, iç kapaklar desensizdir.

Tarihlendirme: "Mecmû'a-i Eş'âr ve Ed'îye" isimli eserin müellifi ve istinsah tarihi belli değildir. 3a ve 4a'da Osman Çelebi'ye ait iki mühür ile 46a'da 1255 yılına ait bir tevellüd kaydı yer almaktadır. Raşit Efendi Kütüphanesi'ndeki 1158 envanter numaralı 1617 yllında istinsah edilmiş olan "Nûr-Nâme" adlı eserle (Özbek, 2005: 120) cildindeki şemse süslemesi ve kullanılan teknik bakımından birebir örtüşmektedir. Bu örnekle olan benzerliği de göz önüne alındığında eserin cildi 17. yüzyılda yenilenmiş olmalıdır.

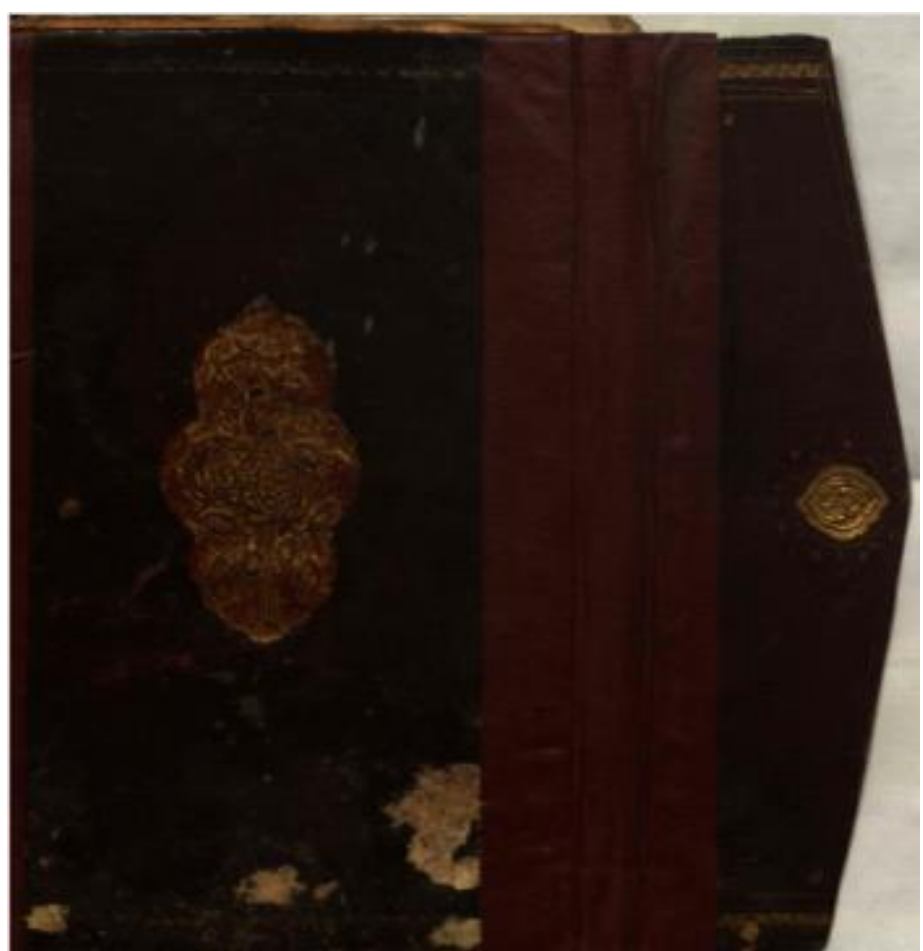

Örnek No: 3

Eser Adı: Şerh-i Vasiyet-i Birgivî 
Bulunduğu Yer: Milli Kütüphane

Envanter No: 06 Mil Yz A 4515/1

Konusu: İslâm Dini-İman ve İslâm

Müellif: Alî Sadrî Kônavî (öl. 1114/1702)

Mücellit: Bilinmiyor

İstinsah Tarihi: 1114 (1701)

Ölçüleri: 210x135-130x70 mm.

Varak Sayısı: 2a-137b

Cilt Yapım Malzemesi: Deri-Meşin

Cilt Rengi: Kahverengi

Cilt Yapım Tekniği: Baskı Tekniği

Cilt Süslemesinde Kullanılan Renkler: Altın

Bezeme: Cildin ön ve arka kapağında aynı bitkisel bezmeye sahip mülemma şemse cilt yer almaktadır. Kitabın kapakları ve miklep, zencirek ile çerçevelenmiştir. Zencirek etrafı dışta ve içte iki sıra altın cetvel ile kuşatılmıştır. Köşebent bezemesi yoktur.

Şemse kapak merkezinde dar, uzun, ortası şişkin ve dilimlidir. Şemse yüzeyi, karışık bukettir. Buket sap kısmından bağlanmıştır. Aşağıda gül, yukarda gül goncası, zerrin ve tanımlanamayan çiçekler vardır. Şemsenin etrafı tahrir yapılmış, tığlarla ve noktalarla süslenmiştir. vardır.

Miklep şemsesi oval formda, yüzeyinde kıvrım dallar üzerinde penç ve yaprak motifleri

Kitabın sertab ve sırt kısmı kahverengi deri ile onarım yapıldığından dolayı görülememiştir.

İç kapaklarında herhangi bir süsleme kompozisyonu bulunmamaktadır.

Tarihlendirme: "Şerh-i Vasiyet-i Birgivî" adlı eserin müellifi "Alî Sadrî Kônavî (öl. 1114/1702)"dir. 1114 (1701) tarihinde istinsah edilen eserin müntensihi ise "İsmail Konevi” dir. Eserin ve cildinin bu tarihlerde meydana getirildiği görüldüğünden cilt 18. yüzyıldan orijinal olmalıdır. İstanbul Üniversitesi Kütüphanesi A. 5582 envanter numaral1 1788 tarihli “Dua Kitabı"nın (Demiriz, 1986: 225) tezhibinde yer alan süsleme ile cilt kapağında yer alan süslemenin benzerliği görülmektedir. 


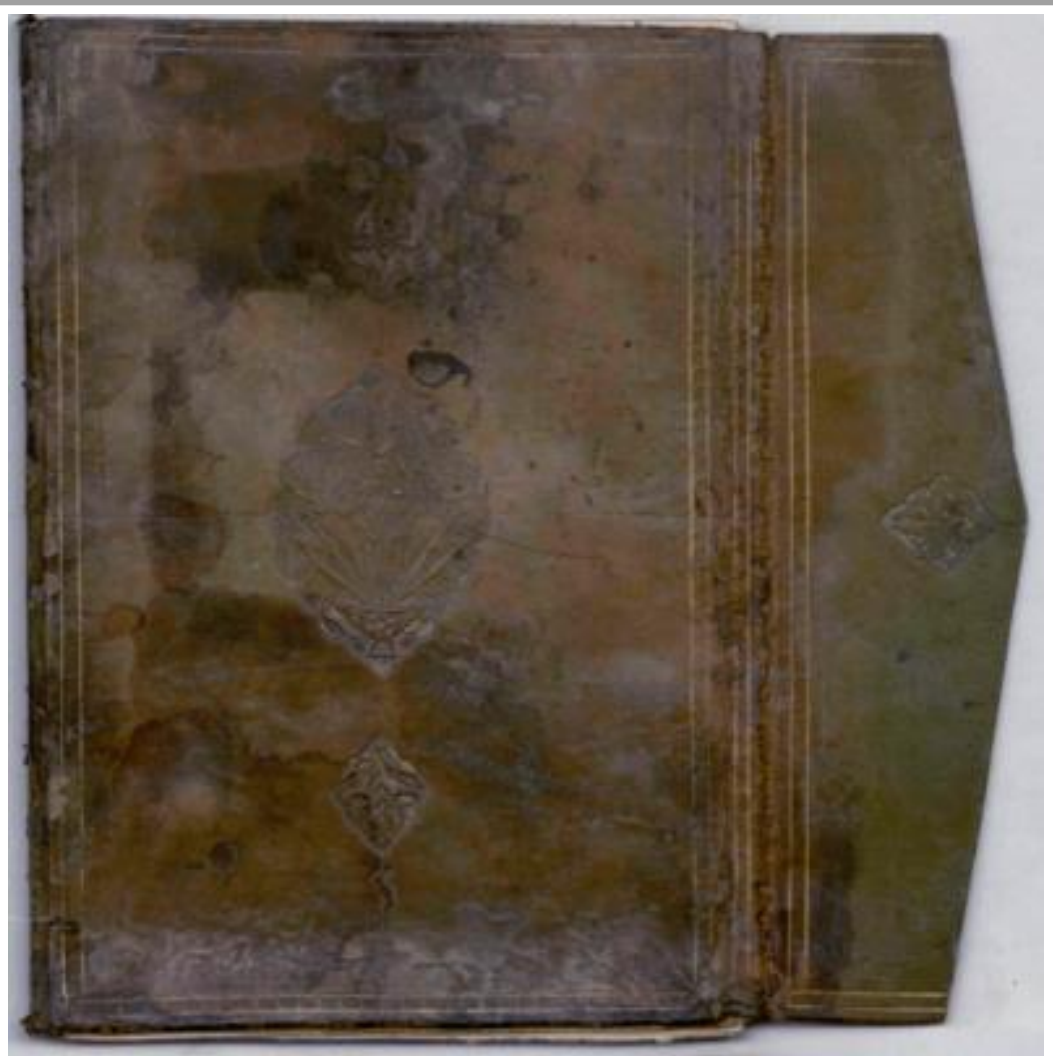

Örnek No: 4

Eser Adı: el-Vesâ'il fî Ma'rifeti'l-Evâ'il

Bulunduğu Yer: Milli Kütüphane

Envanter No: 06 Mil Yz A 1124/1

Konusu: Türk Alemi ve Yakın Doğu

Müellif: Celâleddîn Abdurrahmân b. Ebî Bekr es-Suyûtî

Mücellit: Bilinmiyor

İstinsah Tarihi: 1148 (1735)

Ölçüleri: 200x140 - 150x75 mm.

Varak Sayısı: 1b-24b

Cilt Yapım Malzemesi: Deri-Meşin

Cilt Rengi: Yeşil

Cilt Yapım Tekniği: Baskı Tekniği

Cilt Süslemesinde Kullanılan Renkler: Renk Kullanılmamış

Bezeme: Cildin ön ve arka kapakları aynı bezmeye sahip, soğuk şemse cilt görülmektedir. Kitabın kapakları, miklep ve sertabı iki sıra altın cetvel ile çerçevelenmiştir. Köşebent bezemesi yoktur. 
Şemse kapak merkezinde, dilimli ve oval biçiminde olup salbeklidir. Şemse yüzeyi saksıdan çıkan üç adet zerrin çiçeği, tomurcukları ve yapraklarından oluşmaktadır. Salbek ve miklep şemsesi de palmet formdadır. Formların yüzeyinde zerrin çiçeği görülür. Bezemeler hafif kabartma olarak kalıpla basılmıştır.

Sertab, sırt ve iç kapaklarında herhangi bir süsleme bulunmamaktadır.

Tarihlendirme: “el-Vesâ'il fî̀ Ma'rifeti'l-Evâ'il”'in müellifi “Celâleddîn Abdurrahmân b. Ebî Bekr es-Suyûtî"dir. 1148 (1735) tarihinde istinsah edilen eserin müstensihi "Mustafa b. Mehmed"dir. Eserin ve cildinin bu tarihlerde meydana getirildiği görüldüğünden cilt 18. yüzyıldan orijinal olmalıdır. Türkiye Yazma Eserler Kurumu Başkanlığı Millet Yazma Eser Kütüphanesi A.E. Manzum 1307 "Şükûfename" isimli eser 1780 yılına aittir. "Şükûfename" çoğu (a) yüzlerinde olmak üzere 60 çiçek ve çiçek buketi resmi bulunur (Demiriz, 2019: 255-257) ve cilt kapağındaki vazoda zerrin motifinin benzerleri bu eserin içerisindeki resimlerde görülür.

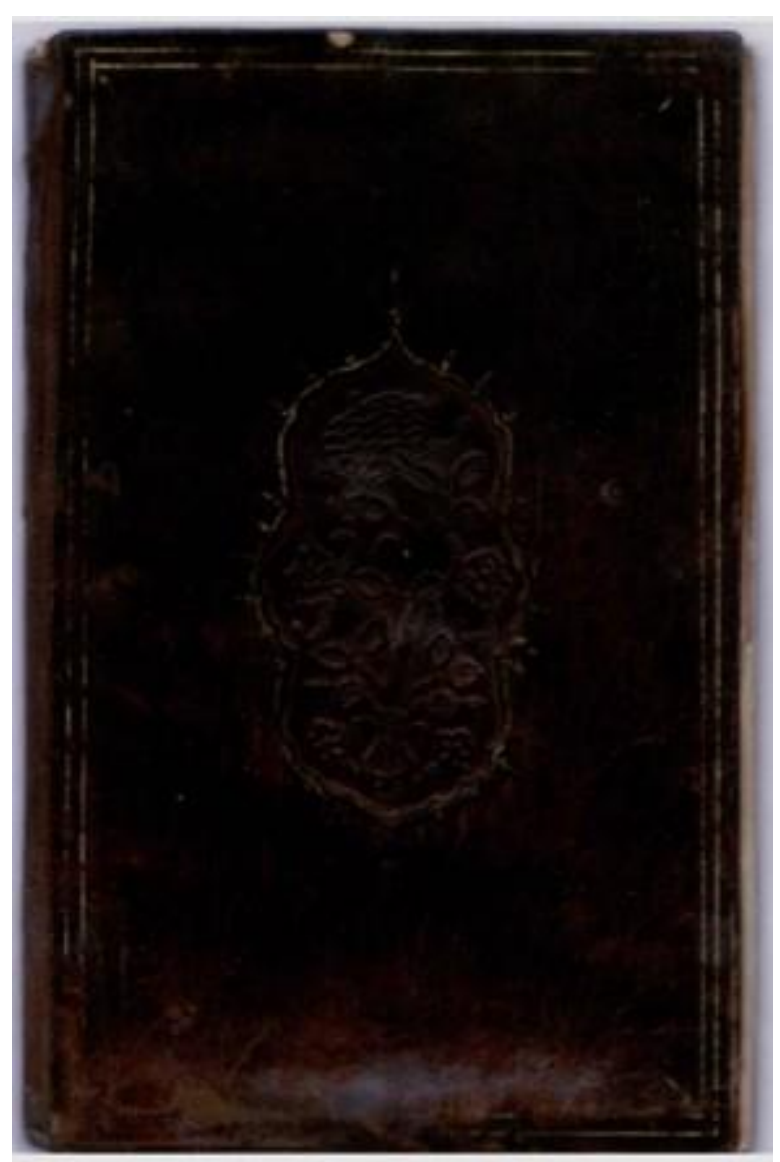

Örnek No: 5

Eser Adı: Mîzânu'l-Hakâik

Bulunduğu Yer: Milli Kütüphane

Envanter No: 06 Mil Yz A 3716

Konusu: Bilinmiyor 
Müellif: Hâmîd b. Fazlallah Cemâlî Dehlevi

Mücellit: Bilinmiyor

İstinsah Tarihi: 866 (1461)

Ölçüleri: 180x110 - 130x65 mm.

Varak Sayısı: 20

Cilt Yapım Malzemesi: Deri-Meşin

Cilt Rengi: Siyah

Cilt Yapım Tekniği: Baskı Tekniği

Cilt Süslemesinde Kullanılan Renkler: Renk Kullanılmamış

Bezeme: Cildin ön ve arka kapağında aynı bitkisel bezmeye sahip soğuk şemse cilt yer almaktadır. Kitabın kapakları altın çekilmiş cetvel ile çerçevelenmiştir. Kapaklarda köşebent bezemesi yoktur ve miklepsizdir.

Şemse kapak merkezinde dar, uzun, ortası şişkin ve dilimli dikdörtgen formdadır. Şemsenin etrafı altın ile tahrir yapılmış, tığlarla süslenmiştir. Şemse yüzeyinde vazodan çıkan gül, gül goncası ve stilize kompozisyonda çiçekler vardır. Bezeme hafif kabartma olarak kalıpla basılmıştır.

Kitabın sırt ve iç kapaklarında herhangi bir süsleme kompozisyonu bulunmamaktadır.

Tarihlendirme: "Mîzânu'l-Hakâik" adlı eser "Hâmîd b. Fazlallah Cemâlî Dehlevi" tarafından yazılmış 866 (1461) tarihinde istinsah edilmiştir. Miklepsiz ciltler ve çiçek buketli bezemelerinin daha çok 18-19. yüzyılla birlikte ortaya çıktığı dikkate alındığında, eserin kapağı 18. yüzyılda yenilenmiş olmalıdır. Raşit Efendi Kütüphanesi 976 envanter numarada kayıtlı 1723 yılında istinsah edilen 'Müntezehü'l-Uyûn ve'l-Elbâb fi Ba'z1'l-Müteahhirine min Ehli'l-Adâb isimli eserle şemse desenindeki benzerlik de dikkati çeker (Özbek, 2005: 86).

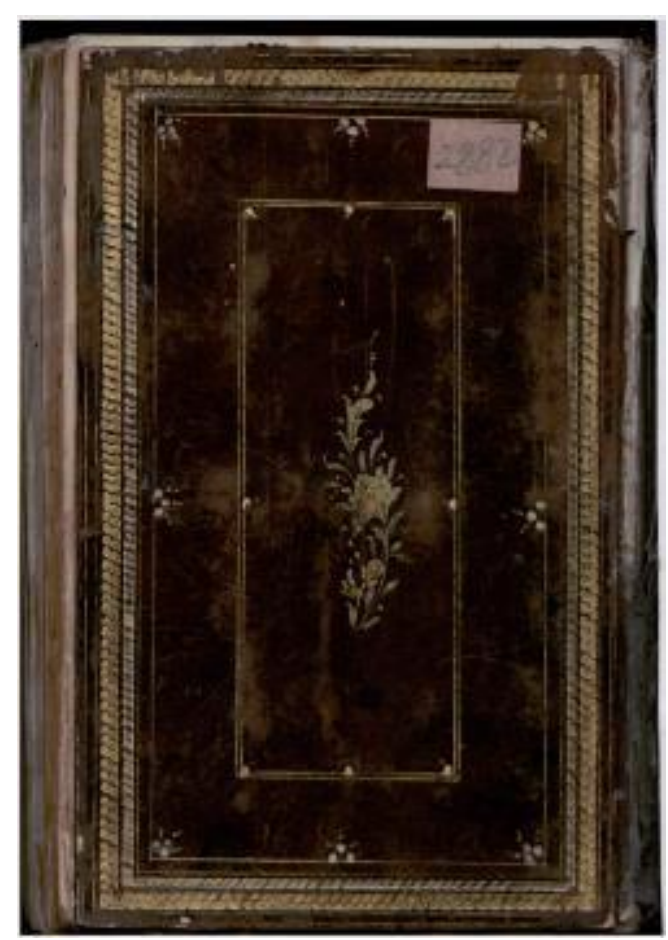

www.turkishstudies.net/social 
Örnek No: 6

Eser Adı: Tevfiku Muvaffaki'l-Hayrât li-Neyli'l-Berekât fî Hidmeti Menba'u's-Sa'âdât

Bulunduğu Yer: Milli Kütüphane

Envanter No: 06 Mil Yz A 2882

Konusu: İslâm Dini-Tasavvuf ve Tarikatlar

Müellif: Kara Dâvud İzmidî

Mücellit: Bilinmiyor.

İstinsah Tarihi: 1247 (1831)

Ölçüleri: 235x143 - 162x73 mm.

Varak Sayısı: 507

Cilt Yapım Malzemesi: Deri-Meşin

Cilt Rengi: Kahverengi

\section{Cilt Yapım Tekniği: Boyama Tekniği}

Cilt Süslemesinde Kullanılan Renkler: Altın, Gümüş

Bezeme: Cildin ön ve arka kapağında aynı bezmeye sahip yazma cilt görülmektedir. Bezemenin tamamında altın ve gümüş kullanılmıştır. Kitabın kapakları altın cetvel arasında biri kalın altın ile renklendirilmiş diğeri ince gümüş renkte iki zencirek ile çerçevelenmiştir. Köşebent bezemesi olmayan eserde köşelerde ve kapak kenar ortalarında üçlü gruplar halinde gülçe motifi görülür. Gülçe motifleri gümüş renktedir.

Kapakta dikdörtgen form oluşturacak şekilde iki sıra cetvel altın ile çekilmiştir. Çerçevenin içerisinde köşelerde ve kenar ortalarında birer adet gülçe motifi vardır. Kapak merkezinde S şeklindeki dalın üzerinde gül, goncası ve yapraklar yer alır. Bitkisel bezeme altın ve gümüş renkte boyanmıştır.

Miklepsiz olan cildin sırt bölümünde herhangi bir süsleme bulunmamaktır.

İç kapaklar zerefşan ile süslenmiştir.

Tarihlendirme: “Tevfiku Muvaffaki'1-Hayrât li-Neyli'l-Berekât fî Hidmeti Menba'u's Sa'âdât" adlı eserin müellifi "Kara Dâvud İzmidî”dir. 1247 (1831) tarihinde istinsah edilen eserin müstensihi "Mehmed Eşref b. Seyid Mehmed Kemal"dir. Hem eserin hem de cildinin bu tarihlerde meydana getirildiği görüldügünden cilt 19. yüzyıldan orijinal olmalıdır. 


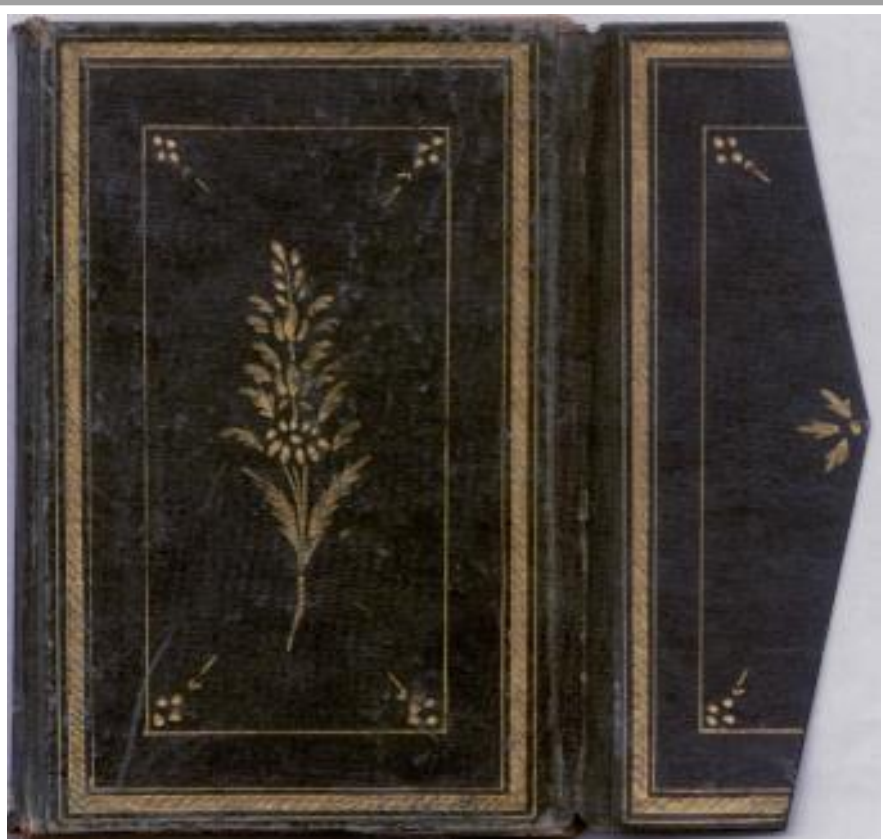

Örnek No: 7

Eser Adı: Tefsîr-i Sûre-i Fatiha

Bulunduğu Yer: Milli Kütüphane

Envanter No: 06 Mil Yz A 2223

Konusu: İslâm Dini-Tefsir Tercüme ve Teviller

Müellif: İsmâ’̂̂l Ankaravî Rüsuhî Dede b. Ahmed (öl. 1042/1632)

Mücellit: Bilinmiyor

İstinsah Tarihi: 1276 (1858)

Ölçüleri: 210x141-150x87 mm.

Varak Sayısı: 169

Cilt Yapım Malzemesi: Deri-Meşin

Cilt Rengi: Yeşil

Cilt Yapım Tekniği: Boyama Tekniği

Cilt Süslemesinde Kullanılan Renkler: Altın

Bezeme: Cildin ön ve arka kapağında aynı bezmeye sahip yazma cilt görülmektedir. Bezemenin tamamında altın kullanılmıştır. Kitabın kapakları ve miklebi iki sıra altın cetvel arasında kalın tekli zencirek ile çerçevelenmiştir.

Köşebent bezemesi olmayan eserin kapak yüzeylerinde bir sıra altın cetvel çekilerek dikdörtgen form elde edilmiştir. Dikdörtgen şeklin köşelerinde dörder adet gülçe motifi ve tığlar görülür. Dikdörtgen formun merkezinde, dal üzerinde yapraklar ve bu yapraklar arasında bir adet papatya vardır. 
Kapaktaki dikdörtgen form miklepte $1 / 2$ ölçüsünde uygulanmıştır. Miklep ucunda iki dişli yapraklarla penç motifinin $1 / 2$ 'si tezyin edilmiştir.

Cildin sırt, sertab ve iç kapaklarında herhangi bir süsleme bulunmamaktır.

Tarihlendirme: “Tefsîr-i Sûre-i Fatiha"nın müellifi İsmâ'îl Ankaravî Rüsuhî Dede b. Ahmed (öl. 1042/1632)'dir. 1276 (1858) tarihinde istinsah edilmiştir. Eserin, hem de cildinin bu tarihlerde meydana getirildiği görüldüğünden cilt döneminden orijinal olmalıdır. Konya Mevlâna Müzesi Müzelik Eserler Bölümündeki 1822 yılında yapılmış 73 envanter numaralı "Divân-1 Kebîr" adlı eserle ((Kara, 2015: 338) süslemesi bakımından küçük farkla birbirine benzemektedirler. Bu fark "Divân-1 Kebîr" cilt kapağı süslemesinde üç papatya olması ve papatyaların gümüş renge boyanmasıdır. "Tefsîr-i Sûre-i Fatiha"da ise tek papatya vardır ve süsleme tamamen altın ile renklendirilmiştir. Kullanılan teknik bakımından da aynıdır.

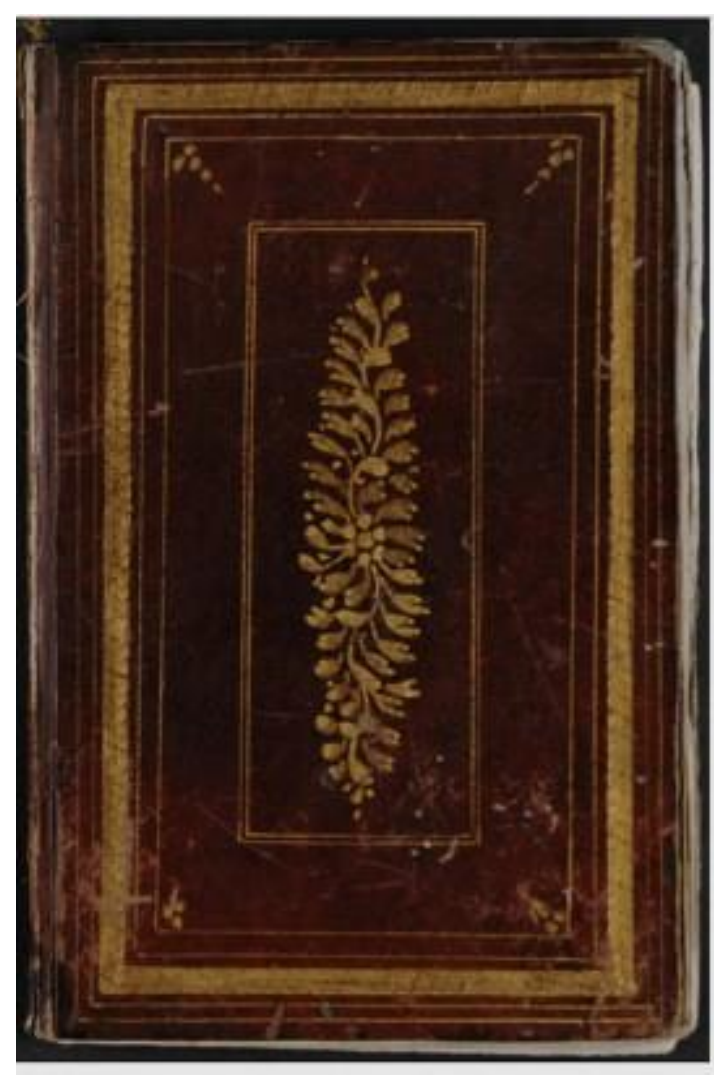

Örnek No: 8

Eser Adı: Divan

Bulunduğu Yer: Milli Kütüphane

Envanter No: 06 Mil Yz A 3011

Konusu: Edebiyat

Müellif: Ruhî Osmân b. Mehmed Bagdâdî (öl. 1014/1605)

Mücellit: Bilinmiyor 
İstinsah Tarihi: 1282 (1864)
Ölçüleri: $200 \times 130-135 \times 75 \mathrm{~mm}$.

Varak Sayısı: 125

Cilt Yapım Malzemesi: Deri-Meşin

Cilt Rengi: Bordo

Cilt Yapım Tekniği: Boyama Tekniği

Cilt Süslemesinde Kullanılan Renkler: Altın

Bezeme: Cildin ön ve arka kapak kompozisyonu aynıdır. Yazma cilt olarak düzenlenen eserin tamamı altınla boyanarak yapılmıştır. Kapaklar dıştan ve içten iki sıra cetvel arasında kalın bir zencirek ile çerçevelenmiştir. Köşebent bezemesi bulunmayan ciltte, cetvel köşelerine gülçe, gülçelerin uçlarına tı̆̆ motifleri ile süsleme yapılmıştır.

Kapak yüzeylerinde iki sıra cetvel çekilerek dikdörtgen form oluşturulmuştur. Dikdörtgen formun merkezinde altı yapraklı penç motifi, motiften çıkan kıvrım dalların taşıdığı yapraklar ile bezenmiştir.

Miklepsiz olarak düzenlenen eserin sırtı ve iç kapakları süslemesizdir.

Tarihlendirme: "Divan” müellifi Ruhî Osmân b. Mehmed Bagdâdî (öl. 1014/1605)'dir. 1282 (1864) tarihinde İstanbul'da Niyazi Mehmed b. İvaz Mehmed tarafından istinsah edilmiştir. Eserin ve cildinin bu tarihlerde meydana getirildiği görüldüğünden cilt 19. yüzyıldan orijinal olmalıdır. Konya Mevlâna Müzesi Müzelik Eserler Bölümünde bulunan 19. yüzyıla tarihlendirilen 2141 envanter numaralı "Kur'an-1 Kerim”in (Kara, 2015: 425) şemse kompozisyonundaki süslemesi ile de benzerlik görülür.

\section{Değerlendirme}

Bu çalışmada Milli Kütüphane Yazma Eserler Koleksiyonu'na ait 17. yüzyıl (Örnek No:1, 2) 18. yüzyıl (Örnek No: 3, 4, 5) 19. yüzyıl da (Örnek No: 6, 7, 8) istinsah edilmiş çiçek bezemeli cilt kapakları incelenmiştir. Bu kitapların bazılarının istinsah tarihi yoktur. İstinsah tarihi ile cilt stili uyum sağlayan örnekler için, istinsah tarihi ciltlerin hazırlanmış olabileceği en yakın tarih olarak kabul edilmiştir. İstinsah tarihi ile cilt stilinin uyumsuz olduğu görülen ciltlerde ise stil kritiği yapılarak tarihlendirme yapılmıştır.

\subsection{Malzeme ve Renk}

Çalışmamız kapsamındaki 8 adet cildin dış kapağında meşin deri görülür. Cilt kapaklarının ikisi bordo (Örnek No: 1, 8), ikisi kahverengi (Örnek No: 3, 6), ikisi yeşil (Örnek No: 4, 7), vişne (Örnek No: 2) ve siyah (Örnek No: 5) renk deri ile kaplanmıştır.

Bir eserin iç kapağında zerefşan (Örnek No: 6) uygulaması yer alır. Geri kalan kitapların iç kapaklarında herhangi bir süsleme görülmez.

\subsection{Teknik}

Eserlerin kapaklarında boyama (Örnek No: 6, 7, 8) ve baskı teknikleri (Örnek No: 1, 2, 3, 4, 5) tespit edilmiştir. Baskı tekniğinde, desenler altın ile boyanırsa "sıcak baskı", desenler sade bırakılırsa "soğuk baskı" adını almaktadır. Soğuk kalıp baskı tekniğinde dört cilt (Örnek No: 1, 3, 4, 5) görülür. Bir ciltte de gömme tekniğine rastlanır. Gömme tekniğinin yapılacağı mukavvaya, süslemenin yapılacağı yer tespit edilir. Tespit edilen kısımlar oyularak çıkartılır ve buraya daha ince bir mukavva yerleştirilir. Mukavvanın üzeri deri ile kaplanır ve süslemenin yapılacağı kısma kalıp

www.turkishstudies.net/social 
basılır. Motifler kapak yüzeyinden 4-5 milimetre aşağıya iner (Örnek No: 2). Soğuk kalıp baskı ve gömme tekniği ile yapılan ciltlerde şemse, salbek, köşebent ve miklep şemsesine uygulanmıştır.

\subsection{Cilt ve Kapağın Bezeme Özellikleri}

Türk ciltlerinde kapaklar taşmaz, kitabın boyutundadır. Sırt düz ve bezemesizdir. Ciltte bezemeler kapak, sertab ve miklep üzerine yapılmış olması, klasik Türk üslubunun özelliklerindendir.

Kapaklar da bölümlere ayrılır ve bir kapaktaki süsleme unsurları şunlardır: cetvel, zencirek, bordür, köşebent, şemse ve salbek'tir.

Cetveller her ciltte görülür. Soğuk cetvel (Örnek No: 1) ve altınla yapılmış cetveller (Örnek No: 2, 3, 4, 5, 6, 7, 8) düz çizgiler şeklinde olup, çoğunlukla birkaç sıra şeklindedir.

Zencireklerin değişik şekilleri görülür. Ciltleri içerisinde çeşitli kalınlıklarda "Sarmal S" diye de adlandırılan "tekli zencirek" süslemesi dikkati çeker. Genellikle iki sıra cetvel arasında altınlı zencirek bulunduğu (Örnek No: 2, 3, 7, 8) gibi kitabın kapakları altın cetvel arasında biri kalın altın renkte diğeri ince gümüş renkte iki zencirek ile çerçevelenmiş (Örnek No: 6) cilt de vardır. Diğer ciltlerde zencirek görülmez (Örnek No: $1,4,5$ ).

Köşebent bezemesi olmayan ciltlerde köşelerde (Örnek No: 2, 8, 6) kısa ve uzun kenar ortalarında gülçe motifleri vardır (Örnek No: 6, 8).

17. yüzyıla ait iki cildin şemsesi dar, uzun, ortası şişkin, dilimli ve dikdörtgen formdadır (Örnek No: 1, 2). 18. yüzyılda da aynı formda şemseler (Örnek No: 3, 5) görüldüğü gibi oval formda şemse de yer alır (Örnek No: 4). 19. yüzyılda şemse formları devam ettirilirken, şemsenin yerine geçebilecek çiçekler, geniş yapraklarda kullanılmaya başlamıştır (Örnek No: 6, 7, 8). Salbekler palmet formunda olup şemseden uzakta olması dikkat çeker (Örnek No: 4). Salbek yerinde gülçe motifi ile çiçek motifi oluşturulmuş süslemelerde görülür (Örnek No: 2).

Cildin arka kapağına bağlı olan üçgen şeklindeki parça olan miklep, çalışmamızda dört ciltte bulunmaktadır (Örnek No: 1, 3, 4, 7). İki cildin miklep şemsesi palmet formunda (Örnek No: 1, 4), bir cildin miklep şemsesi oval formdadır (Örnek No: 3). Miklep yüzey süslemesinde, kapak süslemelerinin 1/2²'si uygulanmış ciltte vardır (Örnek No: 7).

Eserlerin sertab ve sırt bölümünde herhangi bir süsleme kompozisyonu görülmez. Bazı kitapların sertab ve sırt kısmı başka deri ile onarım yapıldığından dolayı görülememiştir (Örnek No: $1,3)$.

\subsubsection{Bezeme Özellikleri}

Natüralizm akımının etkisiyle geleneksel bitki formları 16. yüzyılın ortalarından itibaren natüralist üslupta çiçekler biçiminde görülmektedir (Demiriz, 2019: 15).17. yüzyıla tarihlendirdiğimiz ciltler soğuk şemse cilt (Örnek No: 1) ve mülemma şemse cilt olarak yapılmıştır (Örnek No: 2). Şemse süslemelerinde, vazodan çıkan kısmen simetrik kompozisyonda çiçekler görülür. Gül, karanfil, zerrin, laleler ve stilize, tanımlanamayacak çiçekler vardır. Miklep şemse yüzeyinde de hatayi motifi kullanılmıştır (Örnek No: 1). Mülemma şemseli cildin yüzeyinde ise gül demetinden oluşan kompozisyonla bezenmiştir. Gül demetinin çıkış noktasında tanımlanamayan çiçeklerle süslenmiştir (Örnek No: 2).

18. yüzyıla tarihlendirmiş olduğumuz eserlerin kapaklarında, 17. yüzyılın çiçek bezeme konularının devamının uygulanmış olduğu görülür. Mülemma şemse cilt olarak tasarlanan şemse yüzeyi, karışık bukettir. Buket sap kısmından bağlanmıştır. Aşağıda gül, yukarda gül goncası, zerrin ve tanımlanamayan çiçekler vardır. Miklep şemsesi de penç ve yaprak motifleri ile bezenmiştir (Örnek No: 3). Bu dönemde iki soğuk şemse cilt yer alır. Bu ciltlerden ilkinin şemse yüzeyi saksıdan çıkan üç adet zerrin çiçeği, tomurcukları ve yapraklarından oluşmaktadır. Salbek ve miklep şemsesi 
yüzeyinde de zerrin çiçeği uygulanmıştır (Örnek No: 4). Diğer şemse yüzeyinde vazodan çıkan gül, gül goncası ve stilize kompozisyonda çiçekler vardır (Örnek No: 5).

19. yüzyılda boyama tekniğinde yazma ciltler düzenlenmiş ve eserlerin bezemesi birbirinden farklıdır. Boyama tekniği ile süslenen kapakların üzerinde altının değişik tonları ve gümüş kullanılarak süslemeye hareketlilik getirilmiştir. Dönemin özelliği olarak S ve C kıvrımları şeklinde yapılan çiçekler yüzeye hakimdir. Kapak merkezlerinde bir dal üzerinde yaprakların arasına papatyalar yerleştirilmiştir (Örnek No: 7). Gümüş ve altın ile boyanan yazma cilt kapak bezemesi S şeklindeki dalın üzerinde gül, goncası ve yapraklar vardır (Örnek No: 6). Kapak merkezinde penç motifi, motiften çıkan kıvrım dalların taşıdığı yapraklar ile bezenmiştir (Örnek No: 8).

\section{Sonuç}

Milli Kütüphane A kataloğunda bulunan ciltler üzerine yaptığımız araştırmada Milli Kütüphane Yazma Eserler Koleksiyonu'nda çalışmaya konu olan sekiz adet cilt tespit edilmiştir. Eserlerin seçiminde envanter kayıtlarındaki bilgilerden yararlanılmıştır. Eserleri malzeme, renk, teknik, cilt ve kapağın bezeme özellikleri bakımından değerlendirdiğimizde ikisi 17. yüzyıl (Örnek No: 1, 2), üçü 18. yüzyıl (Örnek No: 3, 4, 5), üçü de 19. yüzyıla (Örnek No: 6, 7, 8) aittir. İncelenen eserlerden biri 15. yüzyılda istinsah edilmiş olmakla birlikte kapaklar 18. yüzyılda yenilenmiştir.

İncelediğimiz eserlerin mücellitleri belli değildir. İncelenen ciltlerin hepsinde malzeme deridir ve hepsinde meşin deri kullanılmıştır. Cilt yapımında tek renk deri uygulanmış ve eserler kahverengi, bordo, yeşil, vişne, siyah renk deri ile kaplanmıştır. Bir eserin iç kapağında zerefşan süslemesi varken diğer iç kapaklar da süsleme görülmez.

17. ve 18. yüzyılda bask1 tekniği görülürken 19. yüzy1lda boyama tekniği görülür. Soğuk şemse cilt, mülemma şemse cilt ve yazma cilt uygulanmıştır. 17 ve 18 . yüzyıl da genellikle dar, uzun, ortası şişkin, dilimli ve dikdörtgen formunda olan şemseler yer alırken 18. yüzyıla ait bir ciltte salbekli oval şemse görülür. 19. yüzyılda ise ciltlerde görülen nerdeyse tüm yüzeyi kaplayacak biçimde ele alınan şemselerdir. Cilt kapakları natüralist üslupta çiçeklerle bezenmiştir. Bezemede kullanılan çiçekler gül, karanfil, zerrin, lale, papatyadan oluşmuş buket tasvirleri göze çarparken; barok ve rokoko üslubunda bezemelerde görülür.

Yazma eserler bilim, sanat ve kültür araştırmaları konusunda en güvenilir kaynaklardır. Cilt sanatında doğru ve nitelikli çalışmaların, gelecek kuşaklara aktarılması tarih, kültür ve sanat değerlerimizin belgelenerek tanıtılması, devamlılığının sağlanması açısından önem taşımaktadır. Geleneksel Sanatlarımız alanında yapılacak olan bu çalışmaların, kültür hazinelerimizin yaşatılması ve ülke tanıtımına katkı sağlayacağı düşünülmektedir.

\section{Kaynakça}

Arıtan, A.S., (1993), “Ciltçilik” Türkiye Diyanet Vakfi İslâm Ansiklopedisi, İstanbul, C.7, s.551-557. Arseven, C.E., (1983), “Cild”, Sanat Ansiklopedisi, İstanbul, C.1, s.341-348.

Aslanapa, O., (1978), “Tarihi Türk Eserlerinin Bugünün Sanatındaki Yeri”, Türk Kültürü, Ankara, S.190, s.591.

Binark, İ., (1987), "Türk Kitapçılık Tarihinde Cilt Sanatı", Fırat Havzası Yazma Eserler Sempozyuтu 5-6 Mayıs 1986, Elâzı̆̆, Fırat Havzası Araştırma Merkezi, s.91-107.

Demiriz, Y., (1986), Osmanlı Kitap Sanatında Natüralist Üslupta Çiçekler, İstanbul, Acar Matbaacılık Tesisleri.

Demiriz, Y., (2019), Osmanlı Kitap Sanatında Doğal Çiçekler, İstanbul, Hayalperest Yayınevi. 
Derman, U., (2012), “Cilt ve Ebru Sanatı”, İslam Sanatları Tarihi, Eskişehir, Anadolu Üniversitesi Yayın1, s.149-169.

Kara, H., (2015), Konya Mevlâna Müzesi Müzelik Eserler Bölümünde Bulunan Osmanlı Dönemi Ciltleri, Selçuk Üniversitesi Sosyal Bilimler Enstitüsü, Yayımlanmamış Doktora Tezi, Konya.

Kara, H., (2017), "Konya'da Üretilen Osmanlı Ciltleri”, Tarihin Peşinde Uluslararası Tarih ve Sosyal Araştırmalar Dergisi, Konya, 18, 161-196.

Özbek, Y., (2005), Kayseri Raşit Efendi Kütüphanesindeki Kitap Kapaklart, Kayseri, Erciyes Üniversitesi Yayını.

Özen, M.E., (1998), Türk Cilt Sanatı, Ankara, Türkiye İş Bankası Yayınları.

Özkeçeci İ., Özkeçeci Ş.B., (2014), Türk Sanatında Tezhip, İstanbul, Yazı Gen Yayıncılık.

Rukanc1, F., Anameriç, H., (2017), "Belgelerle Türk Kütüphanecilik Tarihi (1960-1980): Retrospektif Bir Değerlendirme (II)", Atatürk Üniversitesi Sosyal Bilimler Enstitüsü Dergisi, C.21, S.1, s.71-95.

Sefercioğlu, N., (2005), Türk Milli Kütüphanesi'nin ve Çağdaş Kütüphaneciliğin Kurucusu Adnan Cahit Ötüken, Ankara, Ankara Üniversitesi Basımevi.

Tanındı,Z., (2012), “ Türk Sanatında Kitap” Sakıp Sabancı Müzesi Kitap Sanatları ve Hat Koleksiyonu, İstanbul, s.9-27. 